Article

\title{
Arbuscular Mycorrhizal Fungi Modulate the Crop Performance and Metabolic Profile of Saffron in Soilless Cultivation
}

\author{
Matteo Caser ${ }^{1,+, *(\mathbb{D}}$, Sonia Demasi ${ }^{1,+}+\mathbb{D}$, Íris Marisa Maxaieie Victorino ${ }^{2,3,4}$, Dario Donno ${ }^{1}(\mathbb{D}$, \\ Antonella Faccio $^{2}$, Erica Lumini ${ }^{2}$, , Valeria Bianciotto ${ }^{2}$ and Valentina Scariot ${ }^{1,2}$ (i) \\ 1 Department of Agricultural, Forest and Food Sciences, University of Torino. Largo Paolo Braccini 2, \\ 10095 Grugliasco (TO), Italy; sonia.demasi@unito.it (S.D.); dario.donno@unito.it (D.D.); \\ valentina.scariot@unito.it (V.S.) \\ 2 Institute for Sustainable Plant Protection, National Research Council, Viale Mattioli 25, 10125 Torino, Italy; \\ rismarisamazaieie.victorino@unito.it (Í.M.M.V.); antonella.faccio@ipsp.cnr.it (A.F.); \\ erica.lumini@ipsp.cnr.it (E.L.); valeria.bianciotto@ipsp.cnr.it (V.B.) \\ 3 Department of Life Sciences and Systems Biology, University of Turin. Viale Mattioli 25, 10125 Torino, Italy \\ 4 Biological Science Department, Science Faculty, Eduardo Mondlane University (UEM), Av. Julius \\ Nyerere-Campus Universitário, Maputo 3453, Mozambique \\ * Correspondence: matteo.caser@unito.it; Tel.: +39-011-670-9835 \\ + Both authors contributed equally to this work.
}

Received: 7 March 2019; Accepted: 7 May 2019; Published: 8 May 2019

Abstract: Saffron (Crocus sativus L.) is cultivated worldwide. Its stigmas represent the highest-priced spice and contain bioactive compounds beneficial for human health. Saffron cultivation commonly occurs in open field, and spice yield can vary greatly, from 0.15 to $1.5 \mathrm{~g} \mathrm{~m}^{-2}$, based on several agronomic and climatic factors. In this study, we evaluated saffron cultivation in soilless systems, where plants can benefit from a wealth of nutrients without competition with pathogens or stresses related to nutrient-soil interaction. In addition, as plant nutrient and water uptake can be enhanced by the symbiosis with arbuscular mycorrhizal fungi (AMF), we also tested two inocula: a single species (Rhizophagus intraradices) or a mixture of $R$. intraradices and Funneliformis mosseae. After one cultivation cycle, we evaluated the spice yield, quality (ISO category), antioxidant activity, and bioactive compound contents of saffron produced in soilless systems and the effect of the applied AMF inocula. Spice yield in soilless systems $\left(0.55 \mathrm{~g} \mathrm{~m}^{-2}\right)$ was on average with that produced in open field, while presented a superior content of several health-promoting compounds, such as polyphenols, anthocyanins, vitamin C, and elevated antioxidant activity. The AMF symbiosis with saffron roots was verified by light and transmission electron microscopy. Inoculated corms showed larger replacement corms ( $+50 \%$ ca.). Corms inoculated with $R$. intraradices performed better than those inoculated with the mix in terms of spice quality ( $+90 \%$ ca.) and antioxidant activity $(+88 \%$ ca.). Conversely, the mixture of $R$. intraradices and $F$. mosseae increased the polyphenol content ( $+343 \%$ ca.). Thus, soilless systems appeared as an effective alternative cultivation strategy for the production of high quality saffron. Further benefits can be obtained by the application of targeted AMF-based biostimulants.

Keywords: biostimulants; Crocus sativus; Funneliformis mosseae; glasshouse; protected cultivation; Rhizophagus intraradices; substrate

\section{Introduction}

Crocus sativus L. (saffron) is a flowering plant belonging to the Iridaceae family [1], grown for its red scarlet stigmas that represent the world's highest-priced spice. The market price for high quality 
saffron can reach $15,000-20,000 € \mathrm{~kg}^{-1}$ [2]. This species is widely cultivated in several countries, such as Iran, Italy, Spain, Morocco, France, Greece, China, India and Mexico [3], with an annual spice production that exceeds $220,000 \mathrm{~kg}$ [4].The importance and notoriety of saffron, used since ancient times as a dye, ingredient for the preparation of spirits, and condiment for food, is due to the substances contained in the spice, primarily crocins, picrocrocin and safranal $[5,6]$. These compounds confer the saffron's unique colour, taste, and aroma, and can also have positive biological effects. Saffron active constituents, such as carotenoids (i.e., crocins), polyphenols, and vitamins showed significant antioxidant activity [7-12]. Furthermore, saffron extracts exhibit anti-carcinogenic, anti-depressive, anti-hyperglycemic, hypoglycemic, and memory-enhancing effects $[3,13]$. Crocus satious is a highly hand labour-intensive crop, mainly during flower harvesting and stigma separation. It is traditionally cultivated in small and flat plots, wherein mechanisation is not economically sustainable due to the harvest type and short flowering period [5,8]. Five hundred hand labour hours are needed to obtain 1 $\mathrm{kg}$ of dried saffron $[4,5]$. Saffron cultivation can be carried out on an annual or multi-year cycle $[14,15]$. Annual cultivation guarantees the effective control of plant diseases with a more accurate corm selection. On the contrary, in a multi-year cycle (e.g., 3-4 years in Spain, 4-5 years in Italy, and 6-8 years in India and Greece) [14], corm multiplication and the size of replacement corms in the ground can decrease drastically over the third year [15]. Environment and cultivation management affect flower induction in C. sativus [5,16-18]. In Mediterranean environments, flower induction occurs from early spring to mid-summer, while flower emergence occurs from early- to late-autumn. Differences in the time required for flower initiation have mostly been attributed to the corm size [19]. To produce flowers, the $C$. sativus corm diameter needs to be greater than $1 \mathrm{~cm}$ [20]. As the corm increases, flowering increases [16,21] and occurs in advance [22]. Commercially, a 2.5-3.5 cm diameter corm appears to be the most common size used to have full flowering already during the first cultivation cycle [23]. To increase saffron yield and quality, and to reduce production costs, flowering modulation through cultivation in soilless systems has been proposed $[6,19,24]$. In this cultivation system, plants are grown without the use of soil as a rooting medium and are supplied of inorganic nutrients via the irrigation water [25], and thus can benefit of a wealth of nutrients without competition with pathogens or stresses related to nutrient-soil interaction [26]. However, at present, only limited and controversial reports of saffron soilless cultivation under protected conditions are present in the literature. Molina et al. [18] reported that, in a glasshouse, temperatures may be responsible for production differences in terms of flower induction and flowering duration. Maggio et al. [19] showed that, in southern Italy, cultivation in a cold glasshouse on vermiculite and perlite-based substrates positively affected the yield and number of replacement corms. Similarly, Helal Beigi et al. [27] found that cocopeat and perlite substrates enhanced corm dry weight. While Souret and Weathers [28] and Mollafilabi et al. [24] concluded that soilless cultivation in experiments carried out in France and Iran, respectively significantly decreased the spice yield, in comparison to open field cultivation.

Plant performance in soilless systems may be improved through use of biostimulants, i.e., any natural substance or microorganism applied to plants with the aim to enhance nutrition efficiency, abiotic stress tolerance and/or crop quality traits, regardless of its nutrients content [29], with a consequent decrease of chemicals and increase of sustainability of the production system [30]. Soil microorganisms such as arbuscular mycorrhizal fungi (AMF) are collecting growing interest as biostimulants. They can form mutualistic symbiosis with about $80 \%$ of land plant species, including several crops [31]. Across the interface between the plant and the fungus, carbohydrates and mineral nutrients (i.e., N, P, Zn and B) are exchanged [32]. Thus, AMF can alleviate the limitation in plant growth caused by an inadequate nutrient supply and can improve tolerance to biotic and abiotic stress [33]. Additionally, there is evidence to indicate that AMF symbiosis may have a positive impact on crop quality [34]. Increased yield of essential oils, terpenes and polyphenols, and enhanced antioxidant activity were induced by AMF symbiosis in several medicinal and aromatic plants (MAPs) [12,35-38]. This higher concentration of bioactive molecules makes AMF-hosted plants generally more attractive for the pharmaceutical and food industries [39]. 
The positive effects of AMF on corm growth, spice yield, and the nutraceutical compound content of $C$. sativus have already been reported in open field trials [12,40-42]. However, so far little is known of the proper saffron AMF inocula application and effects in soilless conditions, where plants are cultivated in pots filled with sterilised substrates that are free of AM fungal propagules or highly reduced in AMF diversity [43]. In the meta-analysis performed by Berruti et al. [31], it has been observed that the fungal colonization gain in inoculated plants was significantly more frequent in the greenhouses than in the open-field conditions, even if the effectiveness of AMF inoculation on shoot biomass and yield was equally successful.

Thus, in the literature, saffron cultivation on soilless systems has been proposed for spice production, but no comparison with open field has been reported. While, the effects of AMF-based biostimulants have been investigated only in open fields. To evaluate if saffron cultivation in soilless systems and AMF application may improve crop performance, spice yield and quality, and modulate bioactive compounds content, we cultivated saffron on soilless systems, applying two AMF inocula, and we compared results with those obtained in a previous open field-based trial [12].

\section{Materials and Methods}

\subsection{Plant Material and Soilless Cultivation}

Crocus sativus corms with horizontal diameters of $2.5-3.5 \mathrm{~cm}$, provided by the Azienda agricola "Les épices Vda" di Alessandro Putzolu (Chatillon, AO, Italy), were planted during the last 10 days of August 2017 in the experimental heated glasshouse of the Department of Agricultural Forest and Food Sciences (DISAFA) of the University of Torino (Italy, $45^{\circ} 06^{\prime} 23.21^{\prime \prime} \mathrm{N}$ Lat, $7^{\circ} 57^{\prime} 82.83^{\prime \prime} \mathrm{E}$ Long; $300 \mathrm{~m}$ a.s.1.). Corms were cultivated in pots $(4 \mathrm{~L}, 14 \mathrm{~cm}$ diameter and $17 \mathrm{~cm}$ height; two corms per pot; density of 91 corms $\mathrm{m}^{-2}$ ) filled with sterile quartz sand ( $2 \mathrm{~L}$ per pot; bulk density of $1.2 \mathrm{~kg} \mathrm{~m}^{-3}$ ) on a layer of sterilised expanded clay ( $1 \mathrm{~L}$ per pot; bulk density of $\left.300 \mathrm{~kg} \mathrm{~m}^{-3}\right)$ for a total weight of about $1.5 \mathrm{~kg}$. During the flowering period, the average temperatures were $22{ }^{\circ} \mathrm{C}$ during the day and $14{ }^{\circ} \mathrm{C}$ during the night.

Two inocula (MycAgro Lab, Breteniére, FR) were used in this experiment: one composed of a single fungus Rhizophagus intraradices (Ri) and one composed of $R$. intraradices and Funneliformis mosseae (Ri+Fm). Both inocula consisted of AMF spores and inorganic substrate (calcined clay, vermiculite and zeolite). Inocula treatments were compared to a control without any formulation (AMF-). Ten grams of each inoculum were inserted into each vase. The treatment was placed under each corm in order to guarantee contact between the inoculum and the roots, therefore, favouring mutualistic symbiosis. Corms were not treated for fungal pathogens and cultivation lasted one cycle (August 2017-April 2018).

A complete randomised block design was used, with a total of 48 pots in two experimental plot units (24 pots per unit) and three treatments (8 pots per treatment). Irrigation water (pH 7.4, EC $505 \mu \mathrm{S}$ $\mathrm{cm})$ was added weekly $(250 \mathrm{~mL}$ per pot) with a drip system. The corms were fertilised by fertigation (N:K 13:46; VIGORFLOR, AL.FE. srl, MN, Italy) every 2 weeks starting from the emergence of the spate, in quantities of $1.5 \mathrm{~g} \mathrm{~L}^{-1}$ of water.

\subsection{Determination of Flower Production, Stigma Yield and Corm Growth}

At flowering (October and November 2017), the number of flowers produced daily per corm and the yield of spice (i.e., stigmas dried at $40^{\circ} \mathrm{C}$ for $8 \mathrm{~h}$ in an oven) were measured. The spice yield was calculated by weighting the mg of saffron produced per pot (area equal to $196 \mathrm{~cm}^{2}$ ) and comparing the values to $g$ of spice per square meter $\left(\mathrm{m}^{2}\right)$. At the end of the vegetative period (April 2018), corms were lifted, rid of topsoil, cleaned and de-tunicated, then the number, size and weight of replacement corms were determined. 


\subsection{Preparation of the Saffron Extract}

The saffron aqueous extracts were prepared according to Caser et al. [12]. Briefly, $50 \mathrm{mg}$ of powdered saffron were suspended into $5 \mathrm{~mL}$ of deionised water. After stirring (1000 rpm) for 1 hour at room temperature (circa $21^{\circ} \mathrm{C}$ ) in the dark, the solution was filtered with polytetrafluoroethylene (PTFE, VWR International, Milano, Italy) filters with a $25 \mathrm{~mm}$ diameter and $0.45 \mu \mathrm{m}$ pore size. The saffron extract was then diluted 1:10 with deionised water to obtain the working solution. Each sample was prepared in triplicate.

\subsection{Determination of Saffron Quality by ISO 3632}

Saffron aqueous extracts were analysed with a spectrophotometer (Ultrospec 2100 Pro, Ultrospec 2100 pro, Amersham Biosciences, Uppsala, Sweden) to determine the content of picrocrocin, safranal, and crocin to have the information on the bitterness, the flavouring strength, and the colouring strength [44]. Data were related to the dry matter percentage and expressed as the absorbance of a $1 \%$ aqueous solution of dried saffron at 257,330 and $440 \mathrm{~nm}$ respectively, using a $1 \mathrm{~cm}$ pathway quartz cell [A1\% $1 \mathrm{~cm}(\lambda \max )]$ and calculated according to the following formula [45]:

$$
\mathrm{A} 1 \% 1 \mathrm{~cm}(\lambda \max )=\mathrm{D} \times 10000 / \mathrm{m} \times(100-\mathrm{wMV})
$$

where $\mathrm{D}$ is the specific absorbance; $\mathrm{m}$ is the mass of the evaluated solution in grams; and wMV is the moisture expressed as a percentage mass fraction of the sample.

Moisture content (wMV) was determined using the following formula:

$$
\mathrm{wMV}=(\mathrm{m} 0-\mathrm{m} 1) \times(100 / \mathrm{m} 0) \%
$$

where $\mathrm{m} 0$ is the mass, in grams, of the saffron portion before drying; and $\mathrm{m} 1$ is the mass, in grams, of the dry residue after incubation, performed in an oven for $16 \mathrm{~h}$ at $103 \pm 2{ }^{\circ} \mathrm{C}$.

All analytical steps were conducted in the dark to prevent analyte degradation.

\subsection{Determination of Bioactive Compounds by HPLC}

Bioactive compounds were determined by means of four high performance liquid chromatography-diode array detection (HPLC-DAD) methods (Table 1; [46]) using an Agilent 1200 High-Performance Liquid Chromatograph coupled to an Agilent UV-Vis diode array detector (Agilent Technologies, Santa Clara, CA, USA). Phytochemical separation was achieved with a Kinetex C18 column $(4.6 \times 150 \mathrm{~mm}, 5 \mu \mathrm{m}$, Phenomenex, Torrance, CA, USA) using several mobile phases for compound identification and recording UV spectra at different wavelengths, based on HPLC methods, as previously tested and validated [47], with some modifications. UV spectra were recorded at $330 \mathrm{~nm}$ $(\alpha), 280 \mathrm{~nm}(\beta), 310$ and $441 \mathrm{~nm}(\gamma)$, and 261 and $348 \mathrm{~nm}(\delta)$. All single compounds were identified by a comparison and combination of their retention times and UV spectra with those of authentic standards under the same chromatographic conditions. 
Table 1. Characteristics of the HPLC methods applied to analyse the bioactive compounds present in the studied saffron samples.

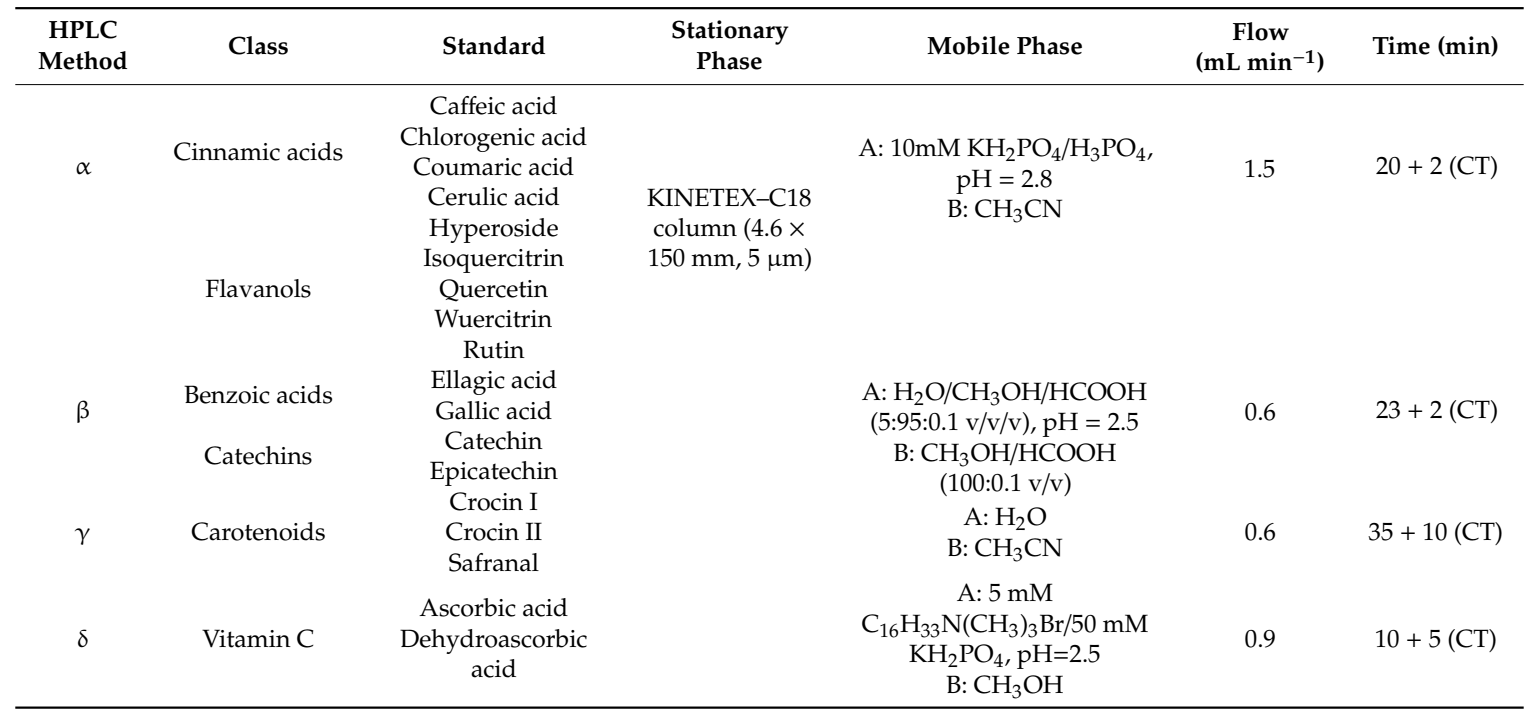

$\mathrm{CT}=$ conditioning time; Method $\alpha$-gradient analysis: $5 \% \mathrm{~B}$ to $21 \% \mathrm{~B}$ in $17 \mathrm{~min}+21 \% \mathrm{~B}$ in $3 \mathrm{~min}+2 \mathrm{~min}$ of conditioning time-wavelength: $330 \mathrm{~nm}$; Method $\beta$ - gradient analysis: $3 \% \mathrm{~B}$ to $85 \% \mathrm{~B}$ in $22 \mathrm{~min}+85 \% \mathrm{~B}$ in $1 \mathrm{~min}+$ 2 min of conditioning time-wavelength: $280 \mathrm{~nm}$; Method $\gamma$-gradient analysis: 5\% B to $95 \%$ B in $30 \mathrm{~min}+95 \%$ B to $5 \% \mathrm{~B}$ in $5 \mathrm{~min}+10 \mathrm{~min}$ of conditioning time-wavelengths: $310 \mathrm{~nm}+441 \mathrm{~nm}$; Method $\delta$-isocratic analysis: $10 \mathrm{~min}+5 \mathrm{~min}$ of conditioning time-wavelengths: $261 \mathrm{~nm}+348 \mathrm{~nm}$.

\subsection{Phytochemical Characterisation}

The phytochemical characterisation of each sample was performed as previously described by Caser et al. [48,49]. Briefly, the total anthocyanin content (TAC) was determined using the pH-differential method. Saffron solution was added to $\mathrm{pH} 1$ and $\mathrm{pH} 4.5$ buffer solutions. The absorbance of samples was determined at 515 and $700 \mathrm{~nm}$ after $15 \mathrm{~min}$ of equilibration. The results were expressed as milligrams of cyanidin 3-O-glucoside $\left(C_{3} \mathrm{G}\right)$ per 100 grams of dry weight $\left(\mathrm{mg}_{\mathrm{C} 3 \mathrm{G}} 100 \mathrm{~g}^{-1} \mathrm{DW}\right)$. The total phenol content (TPC) was measured using the Folin-Ciocalteau phenolic method at $765 \mathrm{~nm}$. The results were expressed as $\mathrm{mg}$ of gallic acid equivalents (GAE) per $100 \mathrm{~g}$ of dry weight (DW; mg $\mathrm{GAE} 100 \mathrm{~g}^{-1}$ DW). The antioxidant activity (AOA) was determined at $595 \mathrm{~nm}$ using the ferric reducing antioxidant power (FRAP) method and at $734 \mathrm{~nm}$ using the 2,2'-azinobis (3-ethylbenzothiazoline-6-sulphonic acid; ABTS) method. Results were expressed as millimoles of ferrous iron $\left(\mathrm{Fe}^{2+}\right)$ equivalents per kilogram of dry weight ( $\left.\mathrm{mmol} \mathrm{Fe}^{2+} \mathrm{kg}^{-1} \mathrm{DW}\right)$ and as $\mu \mathrm{mol}$ of Trolox equivalents per gram of dry weight $(\mu \mathrm{mol}$ $\mathrm{TE} \mathrm{g}^{-1} \mathrm{DW}$ ), respectively. All analyses were performed in three replicates and the absorbances were read using a spectrophotometer (Ultrospec 2100 Pro, Ultrospec 2100 pro, Amersham Biosciences, Uppsala, Sweden).

\subsection{AMF Evaluation}

On the base of saffron highly mycorrhization level (70 to $90 \%$ mycorrhizal intensity) previously reported [12], we randomly selected saffron roots in April 2018. Then, the root segments were processed for observation in light and under transmission electron microscopy. Root segments were excised under a stereomicroscope and quickly fixed in $2.5 \%$ glutaraldehyde in $0.1 \mathrm{M}$ cacodilate buffer $\mathrm{pH}$ 7.2) for 2 hours at room temperature and overnight at $4{ }^{\circ} \mathrm{C}$. The samples were then post-fixed in $1 \%$ OsO4 in the same buffer and dehydrated in an ascending series of ethanol to $100 \%$, incubated in two changes of absolute acetone and infiltrated in Epon-Araldite resin [50]. The resin was polimerised for $24 \mathrm{~h}$ at $60{ }^{\circ} \mathrm{C}$. Semi-thin $(1 \mu \mathrm{m})$ sections were then stained with $1 \%$ toluidine blue and ultra-thin $(70 \mathrm{~nm})$ sections were counter-stained with uranyl acetate and lead citrate [51], and used for electron microscopy analyses under a Philips CM10 transmission electron microscope. 


\subsection{Chemicals and Reagents}

Sodium carbonate, Folin-Ciocalteu phenol reagent, sodium acetate, citric acid, hydrochloric acid, iron (III) chloride hexahydrate, 2,4,6-tripyridyl-S-triazine (TPTZ) and 1,2-phenylenediamine dihydrochloride (OPDA) were purchased from Sigma Aldrich (St. Louis, MO, USA), whereas acetic acid was purchased from Fluka Biochemika (Buchs, Switzerland). Ethylenediaminetetraacetic acid (EDTA) disodium salt was purchased from AMRESCO (Solon, OH, USA), whereas sodium fluoride was purchased from Riedel-de Haen (Seelze, Germany). Ethanol, acetone, sodium citrate and lead nitrate were purchased from Fluka Biochemika. Analytic HPLC grade solvents, methanol and formic acid were purchased from Sigma Aldrich and Fluka Biochemika, respectively; potassium dihydrogen phosphate, ammonium dihydrogen phosphate and phosphoric acid were also purchased from Sigma Aldrich. Milli-Q ultrapure water was produced by Sartorius Stedium Biotech mod. Arium (Sartorius, Goettingen, Germany). Cetyltrimethylammonium bromide (cetrimide) was purchased from Extrasynthése (Genay, France), whereas 1,2-phenylenediamine dihydrochloride (OPDA) was purchased from Sigma Aldrich. All polyphenolic and terpenic standards were purchased from Sigma Aldrich. The organic acids were purchased from Fluka Biochemika, whereas ascorbic acid and dehydroascorbic acid were purchased from Extrasynthése. All chemicals specific for electron and optical microscopy were purchased from Electron Microscopy Sciences (Newark, PA, USA), i.e., glutharaldeyde, cacodylate buffer, osmium tetroxide, epon/araldite resin, toluidine "O" and uranyl acetate.

\subsection{Statistical Analysis}

An arcsin transformation was performed on all percentage incidence data before statistical analysis in order to improve the homogeneity of the variance (Levene test). All the analysed data were checked for the normality of variance. For all the analysed parameters, mean differences were computed using a one-way ANOVA with a Tukey post hoc test $(p \leq 0.05)$. Mean comparisons between data obtained in soilless and those from the first growing season of a previous work conducted in open field [12] cultivations were performed using an independent samples t-test. All analyses were performed using SPSS 24.0 Inc. software (SPSS Inc., Chicago, IL, USA).

\section{Results and Discussion}

\subsection{Crop Performance, Quality and Secondary Metabolite Content of Saffron in Soilless Cultivation}

Soilless cultivation in a glasshouse has been recently proposed as an alternative method to open field cultivation for saffron. Maggio et al. [19] and Gresta et al. [6] reported that, by controlling growth conditions, flowering could be modulated, extended and considerably increased, compared with open field cultivation. In the present study, under protected conditions, flowering had the same duration (ca. 22 days) compared to cultivation of the same corms planted on the same days in a northwestern Italian open field [12], but the saffron flowering moved forward about 20 days (from 5 October 2017 to 23-30 October 2017), in agreement with Gresta et al. [6]. Since, for the flower emergence, corms required to be transferred from $23-27^{\circ} \mathrm{C}$ to $17^{\circ} \mathrm{C}$ [18], the most likely reason for this results is related to the fact that, in a glasshouse, the lowering of seasonal temperatures takes place more slowly than in an open field. In addition to the temperature lowering, Gresta et al. [52] indicated the soil water content as another environmental component that can trigger flowering. However, as in these two studies object of comparison, the cultivation occurred in different substrates (quartz sand vs soil), it appears not possible to make speculations.

Saffron yield can vary from 0.15 to $1.5 \mathrm{~g} \mathrm{~m}^{-2}$, based on planting density, plantation age (from one to six year crop cycles), and climatic conditions during the crop season [1]. In this study, an average of $0.55 \mathrm{~g} \mathrm{~m}^{-2}$ was obtained, indicating a profitable production already during the first year. This yield was similar to what obtained cultivating the same corms at a density of 39 corms $\mathrm{m}^{-2}$ in a northwestern Italian open field [12] and superior to that obtained in south Italy under similar glasshouse conditions by Gresta et al. [6] (corm density equal to 40 corms m$^{-2} ; 0.46 \mathrm{~g} \mathrm{~m}^{-2}$ ) with corms 
coming from Sardinia (Italy). With similar corm density to our work, Cavusoglu and Erkel [53] and Maggio et al. [19] obtained much higher yields $\left(0.88 \mathrm{~g} \mathrm{~m}^{-2}\right.$ and $2.34 \mathrm{~g} \mathrm{~m}^{-2}$, respectively) in glasshouses located in Turkey and south Italy. In Iranian open fields, at a corm density similar to our study, Mollafilabi et al. [24] and Koocheki and Seyyedi [54] obtained an average spice yield of $0.48 \mathrm{~g} \mathrm{~m}^{-2}$. As affirmed by Gresta et al. [52], to trigger saffron flowering, a not yet fully understood combination of temperature and soil water content is needed.

In addition to the spice yield, another economically important attribute of saffron is the number of replacement corms. The obtained values (2.63 replacement corms corm ${ }^{-1}$ ) are lower of those obtained by Maggio et al. [19] in soilless cultivation in a cold glasshouse in south Italy, by using peat and perlite (1:1) substrates, where corms produced from 3.0 to 4.5 replacement corms per corm. In addition to a different substrate, these authors also incubated corms in the dark for 83 days before planting. Thus, the combination of these two factors could have guarantee a superior result. Comparing to open field experiments that used corms with similar size to our study, results were in agreement with those from our trial in northwest Italy [12], and the trials performed by Turhan et al. [55] in Turkey (2.32 replacement corms corm $^{-1}$ ), while superior to those obtained by Koocheki and Seyyedi [54] in Iranian fields (1.32 replacement corms corm $^{-1}$ ).

Guidelines for the analyses of the main compounds that contribute to the sensory profile of saffron have been established by ISO 3632 regulations [44]. These regulations define procedures to determine these compounds by spectrophotometric analyses and have established the limits by which saffron quality is classified into three different categories (first, second and third). Specifically, the saffron produced under soilless conditions belongs to the highest quality, i.e., first category, for all the studied parameters.

The evaluation of antioxidant activity is generally considered as an important method to evaluate the nutraceutical properties of food, as indicated in other previous studies [30]. Apart from crocins, Karimi et al. [56] and Asdaq and Inamdar [57] highlighted that phenols and flavonols are responsible for the antioxidant potential of saffron. Overall, the saffron produced in soilless systems showed a very high TPC (4445.4 mg $\left.\mathrm{GAE} 100 \mathrm{~g}^{-1} \mathrm{DW}\right)$, more than the saffron cultivated in other sites in the Alps (range between 1340 and $2355 \mathrm{mg}_{\mathrm{GAE}} 100 \mathrm{~g}^{-1} \mathrm{DW}$ ) [12], Lebanon (160 $\left.\mathrm{mg}_{\mathrm{GAE}} 100 \mathrm{~g}^{-1} \mathrm{DW}\right)$ [58], and India ( $828 \mathrm{mg}_{\mathrm{GAE}} 100 \mathrm{~g}^{-1} \mathrm{DW}$ ) [8]. In terms of antioxidant activity, FRAP values were superior to those of Iranian and Italian samples (circa 570 and $1250 \mathrm{mmol} \mathrm{Fe}^{2+} \mathrm{kg}^{-1}$ ) [12,56] and ABTS values were comparable to those found in Italian and Greek saffron by Caser et al. [12] and Ordoudi et al. [59].

\subsection{AMF Colonisation}

In our study, the presence of AMF and their colonisation of saffron roots were confirmed by observations using light microscopy (Figure 1) and transmission electron microscopy (TEM; Figure 2) on semi-thin and thin sections, respectively. Observations on semi-thin sections, stained in blue, show that the saffron roots are mycorrhised when inoculated with both inocula (Figure 1A-C), confirming the mycorrhizal intensity described in Caser et al. [12]. At the level of the cortical root parenchyma, the typical mycorrhizal arbuscular fungal structures have been highlighted (insets Figure 1A,C). Figure 1 shows the presence of intercellular and intracellular hyphae (Figure 1C) and arbuscules (Figure 1A,B). No fungal structures were found in the roots of the control treatments (Figure 1D). 

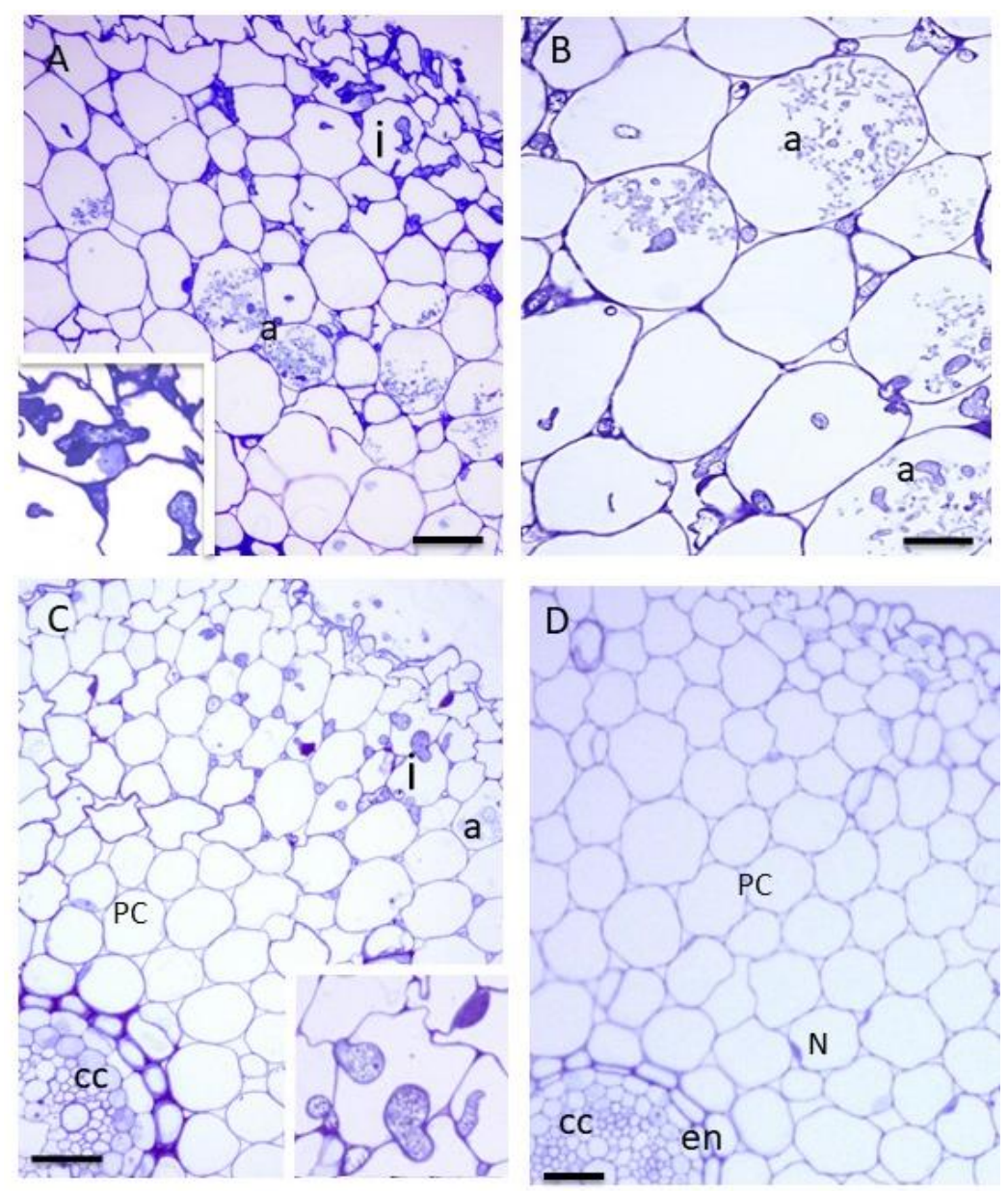

Figure 1. Light microscope images of semi-thin sections of Crocus sativus roots inoculated with Rhizophagus intraradices and Funneliformis mosseae (Ri+Fm, A), R. intraradices alone (Ri, B and C) or the control (arbuscular mycorrhizal fungi (AMF)-, D), stained with toluidine blue. At the level of the cortical cells, note the presence of intercellular and intracellular hyphae (i) and arbuscules (a). Magnification in insets A and C shows details of the intracellular hyphae. Cortical parenchyma (PC) cells with nucleus $(\mathrm{N})$ are indicated. No fungal structure is present between and inside the root cells in AMF-roots (D). Note the central cylinder (cc) and the endodermide (en). Bars are $20 \mu \mathrm{m}$ in A, C and D, and $10 \mu \mathrm{m}$ in $\mathrm{B}$.

Here, the host plasma membrane invaginates and proliferates around all the developing intracellular fungal structures, and cell wall material is laid down between this membrane and the fungal cell surface. The exchange of molecules between the fungal and plant cytoplasm takes place both through their plasma membranes and their cell walls; a functional compartment, known as the symbiotic interface, is thus defined. At the electron microscope level, as seen in Figure 2A,C (arrows), this new apoplastic space, based on membrane proliferation, is evident around the intracellular and arbusculated hyphae of the AMF penetrated inside the saffron root cortical cells. On the basis of TEM observations, we can conclude that the mycorrhizae, formed between saffron roots and the two species of AM fungi in the inocula used in pot experiments, are alive and functionally active. 

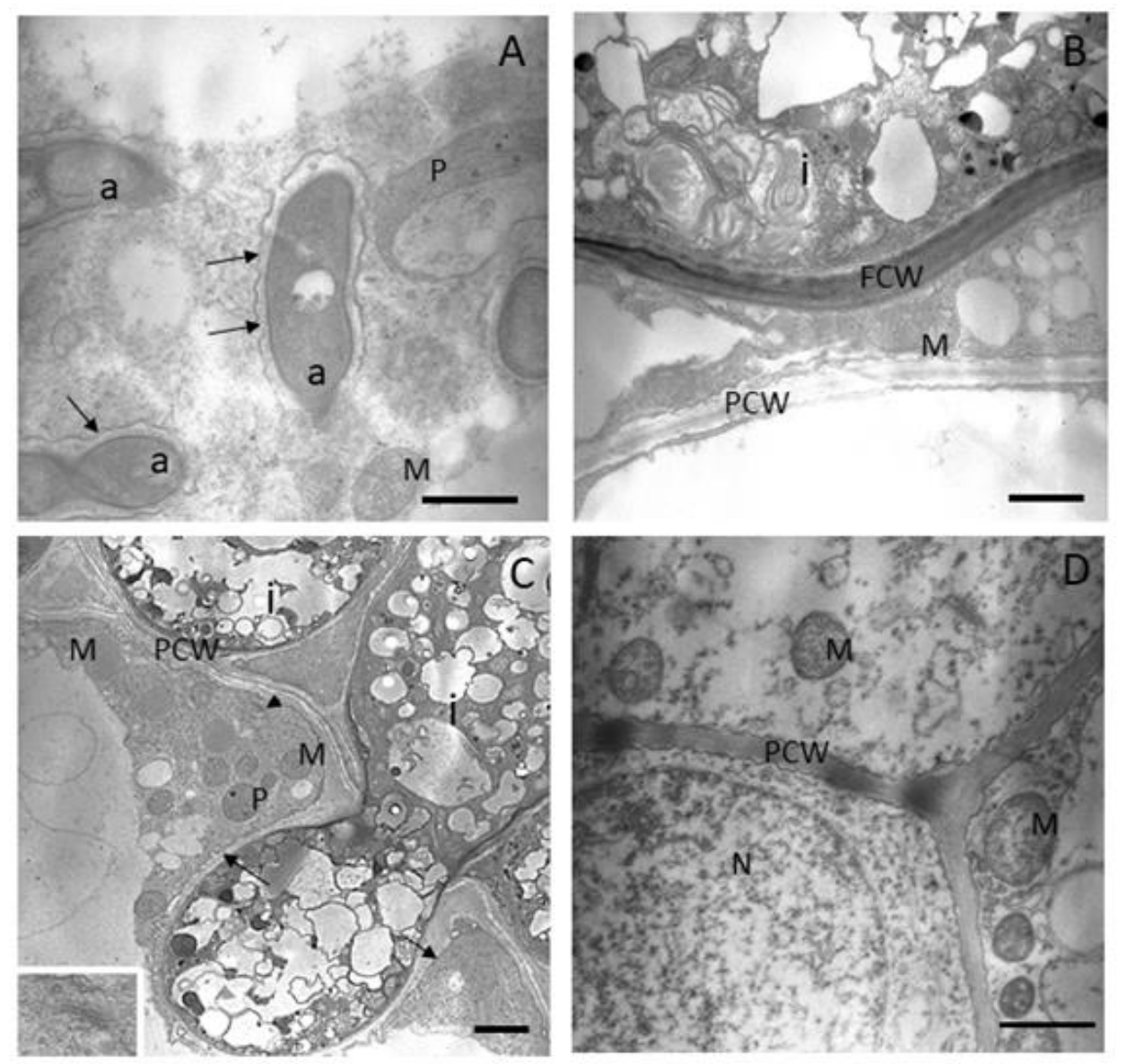

Figure 2. Transmission electron microscopy images of thin sections of saffron roots colonised by Rhizophagus intraradices and Funneliformis mosseae ( $\mathrm{Ri}+\mathrm{Fm}, \mathrm{A}), \mathrm{R}$. intraradices alone (Ri, B and C) or the control (AMF-, D). In details, a: fungal arbuscule; N: nucleus; M: mithocondria; P: plastids; i: fungal hyphae; PCW: plant cell wall; FCW: fungal cell wall; arrow: plant plasmamembrane; arrowhead and inset: Golgi apparatus. The bar is $1 \mu \mathrm{m}$ in $\mathrm{A}, \mathrm{B}, \mathrm{C}$ and D.

\subsection{Impact of AMF on Saffron in Soilless Cultivation}

\subsubsection{Crop Performance and Quality Classification}

In the present study, slight differences in flowering time and production were detected between treated corms (Figure 3 and Table 2). Both applied inocula (Ri and Ri+Fm) anticipated saffron flowering time of one week, compared to untreated corms (AMF-; 23 October vs. 30 October), whereas the flowering peaks and end of flowering occurred in about the same number of days (6-9 November and 11-13 November, respectively).

No significant differences were observed between the treatments in terms of the number of flowers $\mathrm{corm}^{-1}$ and the obtained $\mathrm{mg}$ of spice flower ${ }^{-1}$ (Table 2). Very few reports about the effective role of AMF in saffron flowering and yield are available in the literature, and only under open field conditions. Aimo et al. [40] and Caser et al. [12] indicated a positive role of AMF on the saffron productive performance, with an increase in flower production $(+68 \%$ and $+138 \%$, respectively, compared to the untreated corms) using AMF species belonging to the genus Glomus. 
Table 2. Effects of AMF inoculum composed of Rhizophagus intraradices alone (Ri), R. intraradices and Funneliformis mosseae (Ri+Fm) or the control (AMF-) on yield performances (flower corm ${ }^{-1}$ and saffron flower ${ }^{-1}$ ), growth (number of replacement corms corm $^{-1}$; replacement corm size and weight variation between the end and beginning of the trial) and mean absorbance values for picrocrocin, safranal and crocin of saffron samples obtained during glasshouse cultivation.

\begin{tabular}{|c|c|c|c|c|c|c|c|c|}
\hline \multirow[b]{2}{*}{ Treatment } & \multicolumn{2}{|c|}{ Yield } & \multicolumn{3}{|c|}{ Replacement corm } & \multicolumn{3}{|c|}{ Quality category (ISO3632 [44]) } \\
\hline & $\begin{array}{c}\text { Flower corm }{ }^{-1} \\
(\mathrm{n})\end{array}$ & $\begin{array}{c}\text { Saffron } \\
\text { flower }^{-1}(\mathrm{mg})\end{array}$ & Size (\%) & $\operatorname{Corm}^{-1}(\mathrm{n})$ & Weight (\%) & $\begin{array}{c}\text { Picrocrocin }\left(\mathrm{A}^{1 \%}{ }^{1 \%} \mathrm{~cm}\right. \\
(\lambda 257)\end{array}$ & $\begin{array}{c}\text { Safranal }\left(\mathrm{A}^{1 \%}{ }_{1}{ }_{1 \mathrm{~cm}}\right. \\
(\lambda 330)\end{array}$ & $\begin{array}{c}\text { Crocin }\left(\mathbf{A}^{1 \%}{ }_{1 \mathrm{rm}}\right. \\
(\mathbf{\lambda 4 4 0 )}\end{array}$ \\
\hline $\mathrm{Ri}$ & $0.84 \pm 0.62$ & $6.8 \pm 1.3$ & $45.8 \pm 4.6 \mathrm{a}$ & $2.71 \pm 1.53$ & $7.8 \pm 5.6$ & $143.8 \pm 4.6(\mathrm{I})^{\beta} \mathrm{a}$ & $61.0 \pm 5.3(\mathrm{I}) \mathrm{a}$ & $422.6 \pm 4.1(\mathrm{I}) \mathrm{a}$ \\
\hline $\mathrm{Ri}+\mathrm{Fm}$ & $0.66 \pm 0.60$ & $6.0 \pm 1.4$ & $54.6 \pm 6.2 \mathrm{a}$ & $2.25 \pm 0.95$ & $8.6 \pm 3.8$ & $124.3 \pm 3.9(\mathrm{I}) \mathrm{c}$ & $30.7 \pm 3.4(\mathrm{I}) \mathrm{c}$ & $164.2 \pm 3.8(\mathrm{III}) \mathrm{c}$ \\
\hline$\underset{p}{\mathrm{AMF}-}$ & $\begin{array}{c}0.97 \pm 0.53 \\
\text { ns }\end{array}$ & $\begin{array}{c}6.6 \pm 0.4 \\
\text { ns }\end{array}$ & $33.1 \pm 6.8 \mathrm{~b}$ & $\begin{array}{c}2.63 \pm 1.06 \\
\text { ns }\end{array}$ & $\begin{array}{c}12.6 \pm 5.1 \\
\mathrm{~ns}\end{array}$ & $135.9 \pm 3.4(\mathrm{I}) \mathrm{b}$ & $54.3 \pm 6.7(\mathrm{I}) \mathrm{b}$ & $\begin{array}{c}324.7 \pm 5.9(\mathrm{I}) \mathrm{b} \\
* * *\end{array}$ \\
\hline
\end{tabular}

Mean values with the same letter are not statistically different at $p \leq 0.05$, according to a Tukey post hoc test. The statistical relevance of 'Between-Subjects Effects' tests ${ }^{* * *} p<0.001$, ns $=$ not significant). ${ }^{\beta}$ The quality category (ISO3632) is indicated in brackets. The limits for the first (I) quality category are: picrocrocin $>70$; safranal 20-50; crocins $>200$. ISO3632 limits for the second (II) quality category are: picrocrocin $>55$; safranal 20-50; crocins $>170$. ISO3632 limits for the third (III) category are: picrocrocin $>40$; safranal 20-50; crocins $>120$ 


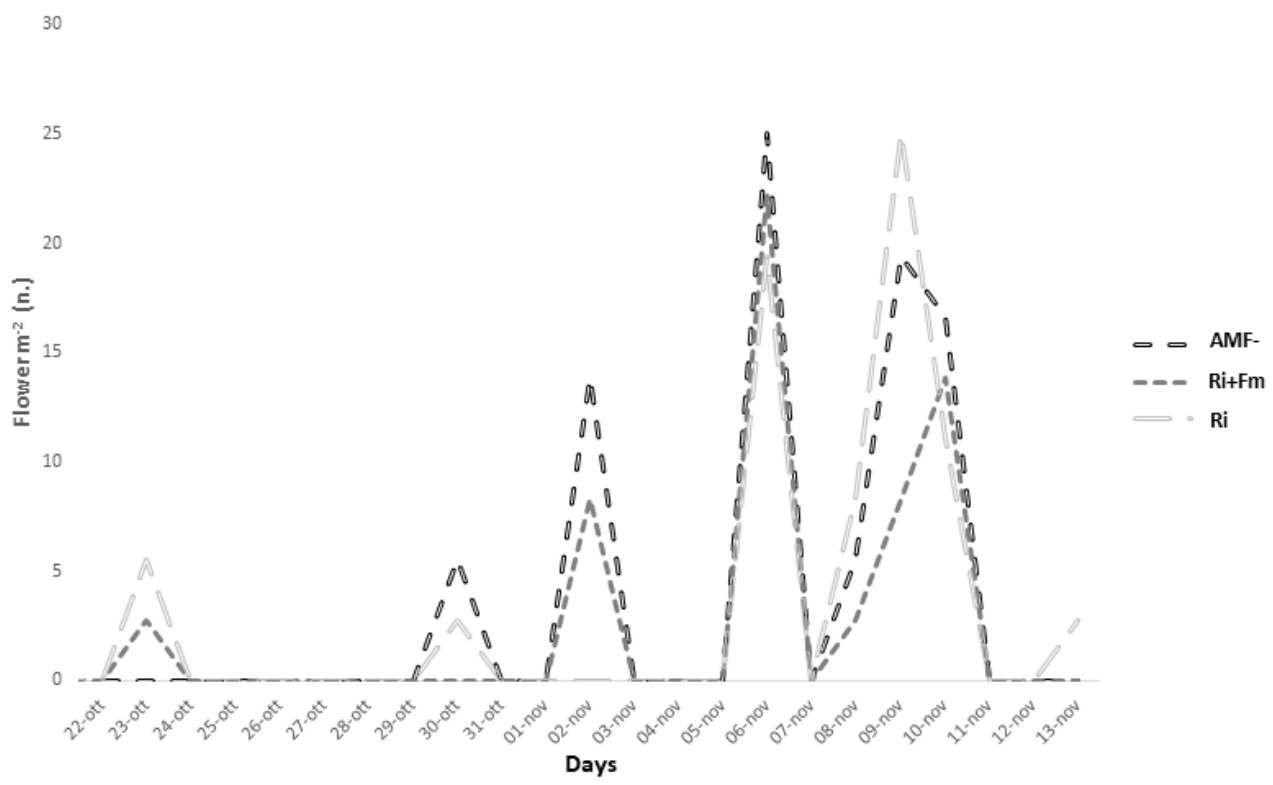

Figure 3. Effects of AMF inoculum composed of Rhizophagus intraradices alone (Ri), R. intraradices and Funneliformis mosseae ( $\mathrm{Ri}+\mathrm{Fm}$ ) or the control (AMF-) on the flowering calendar of Crocus sativus corms and the daily number of picked flowers $\mathrm{m}^{-2}$ during soilless cultivation.

Both of the AMF inocula increased the size of replacement corms in comparison to untreated corms (Table 2), suggesting a positive effect on flower production for the following cultivation cycle, in agreement with Aimo et al. [40] and Mohebi-Anabat et al. [39]. Corm size is indeed a major factor in bulbous plants to determine the flowering capacity and production of new replacement corms $[5,42]$.

Saffron quality greatly depends on the growing conditions $[12,60]$. In the present study, among the AMF inocula, $R$. intraradices alone significantly increased the content of picrocrocin (bitterness), safranal (flavouring strength) and crocins (colouring strength), in comparison to the other treatments. On the contrary, Ri+Fm significantly reduced the content of these molecules and, thus the quality of the spice, in particular by lowering the crocin content to the third category of ISO 3632. To the best of our knowledge, this is the first report indicating the effect of AMF on the quality (ISO) of saffron obtained by soilless cultivation. The positive role of Ri on the increase of the saffron quality, especially on the content of picrocrocin, was highlighted also in northwestern Italian open field [12]. Thus, the corm inoculation with Ri could further increase the already high quality saffron produced in the Italian Alps [45,61].

\subsubsection{Saffron Metabolic Profiling Comparing to Other Foods}

In addition to the peculiar organoleptic characteristics, the stigmas of the C. sativus flower contain many secondary metabolites with demonstrated pharmacological effects [3,11,62-64]. The identification and quantification of bioactive compounds in saffron and the evaluation of their biological activities are important to gauge their potential efficacy in food and pharmaceutical industries [65]. The range of all chemicals can vary greatly as a result of growing conditions, such as in response to the application of biostimulants [63]. Inoculation with AMF is known to alter the production of secondary metabolites in MAPs, both in roots, shoots, and flowers, even if is not consistent among plant organs [66]. The effects of AMF inocula on the biosynthesis of secondary metabolites in saffron are presented in Table 3. This more in-depth analysis confirmed the results obtained by assessing the spice quality according to ISO3632 guidelines. The single species inoculum Ri significantly increased the content of crocins (crocin I and II), whereas the mix Ri+Fm decreased it; these findings are in agreement with those obtained by Caser et al. [12] under field conditions in a temperate mountain area (north-west Italy), where the saffron obtained by corms inoculated with Ri resulted in superior quality (i.e., quality compared to 
the ISO standards). Regarding antioxidant activity (AOA), inoculation with Ri resulted in superior values in both used methods (FRAP and ABTS). The AMF inoculum composed of Ri+Fm significantly increased the contents of isoquercitrin and the total phenolic (TPC) compared to Ri, while of ellagic acid in comparison to Ri and AMF-. Differences in results according to the AMF inoculum composition were also observed in other plant species cultivated on different substrates. Among the reviewed studies, it has been found that the single inoculation of $R$. intraradices tend to be more successful for bioactive compounds increase than inoculation experiments with more than one species applied at the same time. In Echinacea purpurea Moench. [67] cultivated in a sand and soil (1:1) substrate, R. intraradices alone increased more the content of polyphenols than the mixed inoculum, while in Cynara cardunculus L. cultivated in sandy soil [68] and Lactuca sativa L. cultivated in a mixture of peat, sandy loam soil and calcinated clay (1:1:1) [69] $R$. intraradices enhanced more the antioxidant activity. However, it has not been observed any effect on the accumulation of polyphenols in Ocimum basilicum L. cultivated in a sterilised sand and soil (3:1) substrate [70] and in Salvia officinalis L. in sand, soil, and expanded clay $(1: 1: 1)[71,72]$.

Table 3. Bioactive compounds, anthocyanins, total polyphenol content and antioxidant activity (ferric reducing antioxidant power (FRAP) and 2,2'-azinobis(3-ethylbenzothiazoline-6-sulfonic acid) (ABTS); antioxidant activity (AOA)) of the saffron produced via glasshouse cultivation with AMF inocula composed of Rhizophagus intraradices alone (Ri), R. intraradices and Funneliformis mosseae (Ri+Fm) or a control (AMF-).

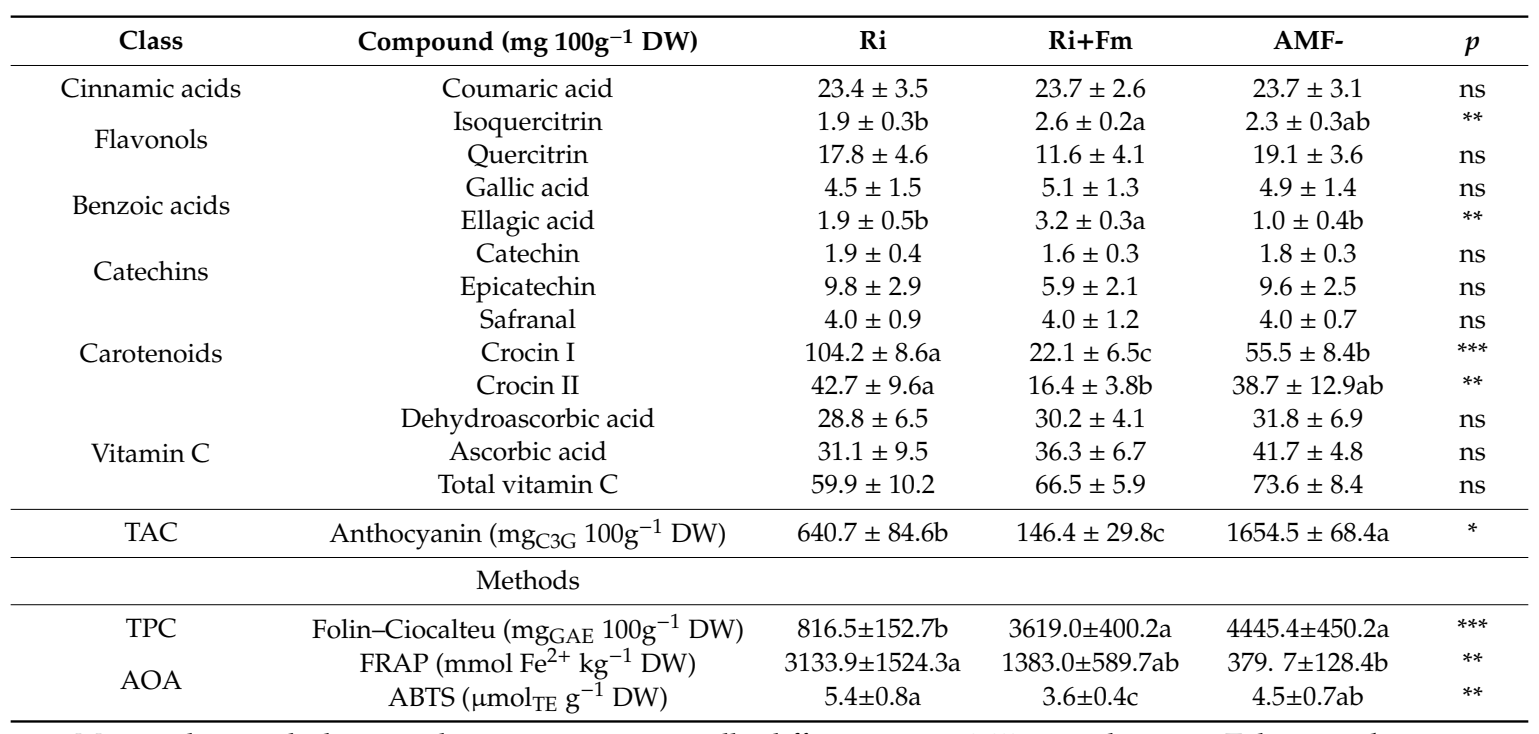

Mean values with the same letter are not statistically different at $p \leq 0.05$, according to a Tukey post hoc test.

The statistical relevance of 'Between-Subjects Effects' tests $\left({ }^{*} p<0.05,{ }^{* *} p<0.01,{ }^{* * *} p<0.001\right.$, ns $=$ not significant).

Karimi et al. [56] and Rahaiee et al. [63] indicated that the antioxidant capacities of saffron might be due to the presence of total phenolics and flavonoids. Based on the obtained results, the content of the bioactive compounds detected in saffron could be compared to other commonly eaten fruits with highly advantageous nutritive properties. Saffron had a higher total phenol content (TPC) and antioxidant activity (AOA) than fresh Ribes nigrum L. berries (circa $+1000 \%$ and $+493 \%$, respectively), and fresh (circa $+2000 \%$ and $+1800 \%$, respectively) and dried (circa $+900 \%$ and $+1650 \%$, respectively) Lycium spp. fruits [65,73], analysed with the same method. Since saffron showed an antioxidant activity superior than $500 \mathrm{mg}_{\mathrm{GAE}} 100 \mathrm{~g}^{-1}$ it could be also listed within the health beneficial fruits such as Rubus glaucus Berth. and Prunus serotina var. Capulì as suggested by Vasco et al. [74]. Its content of vitamin $\mathrm{C}$ was similar to what found in Actinidia deliciosa (A.Chev.) C.F.Liang \& A.R.Ferguson and Citrus sinensis (L.) Osb., and even higher than in Lycium spp. (+150\%) and Vaccinium spp. (+580\%). Also, the coumaric acid content was superior (+85\%) than in Morus nigra L. fruits [75] while lower than in Lycium spp. fruits, that showed also higher content of gallic acid, ellagic acid, catechin, and epicatechin 
was generally lower in saffron (on average circa $-75 \%,-70 \%,-92 \%$, and $-95 \%$, respectively) $[73,75]$. Lastly, the content of anthocyanins, that are suggested to have neuroprotective properties [76], was up to $11654.5 \mathrm{mg}_{\mathrm{C} 3 \mathrm{G}} 100 \mathrm{~g}^{-1} \mathrm{DW}$, i.e., a value very high in comparison to fresh fruit extracts from Morus nigra, Rubus idaeus L., and Fragaria ananassa D. (80.0, 33.7, and $35.2 \mathrm{mg}_{\mathrm{C} 3 \mathrm{G}} 100 \mathrm{~g}^{-1}$, respectively) [75].

\subsubsection{Soilless Cultivation vs. Open Field}

Saffron root colonisation by AMF could be affected by the cultivation conditions related to the substrate composition, root temperature or the presence of antagonistic fungi naturally occurring in the soil $[31,40,41,76]$. In our recent studies, AM fungal colonisation was noted in C. sativus roots inoculated with Ri and Ri+Fm, both in soilless (Figures 1 and 2) and in open field conditions [12]. Figures 4 and 5 report the comparisons of the results obtained by these studies. Compared to open field, in soilless conditions not-inoculated corms (AMF-) showed similar spice yields but with higher quality while, referring to AMF treatments, Ri-inoculated corms produced less spice but with a higher quality, whereas $\mathrm{Ri}+\mathrm{Fm}$ inoculated corms produced less spice, with a lower quality (i.e., reduction in crocin content).

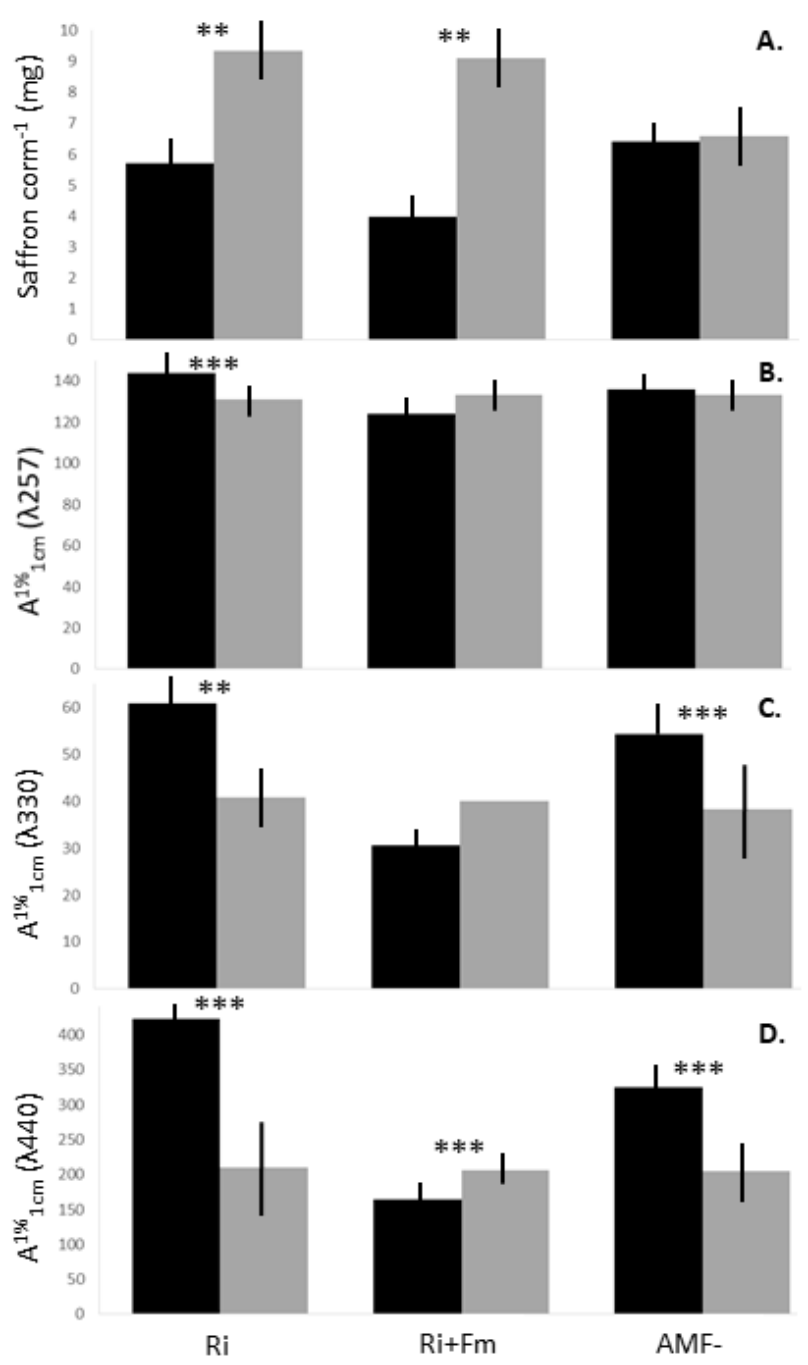

Figure 4. Effects of AMF inoculum consisting of Rhizophagus intraradices alone (Ri), R. intraradices and Funneliformis mosseae ( $\mathrm{Ri}+\mathrm{Fm}$ ) or a control (AMF-) on (A.) $\mathrm{mg}$ of saffron corm ${ }^{-1}$, (B.) picrocrocin, (C.) safranal, and (D.) crocin of Crocus sativus corms cultivated in soilless (black bars) and open field (grey bars, [12]) conditions. Mean comparisons of each treatment in the two cultivation types were performed using an independent samples t-test. 


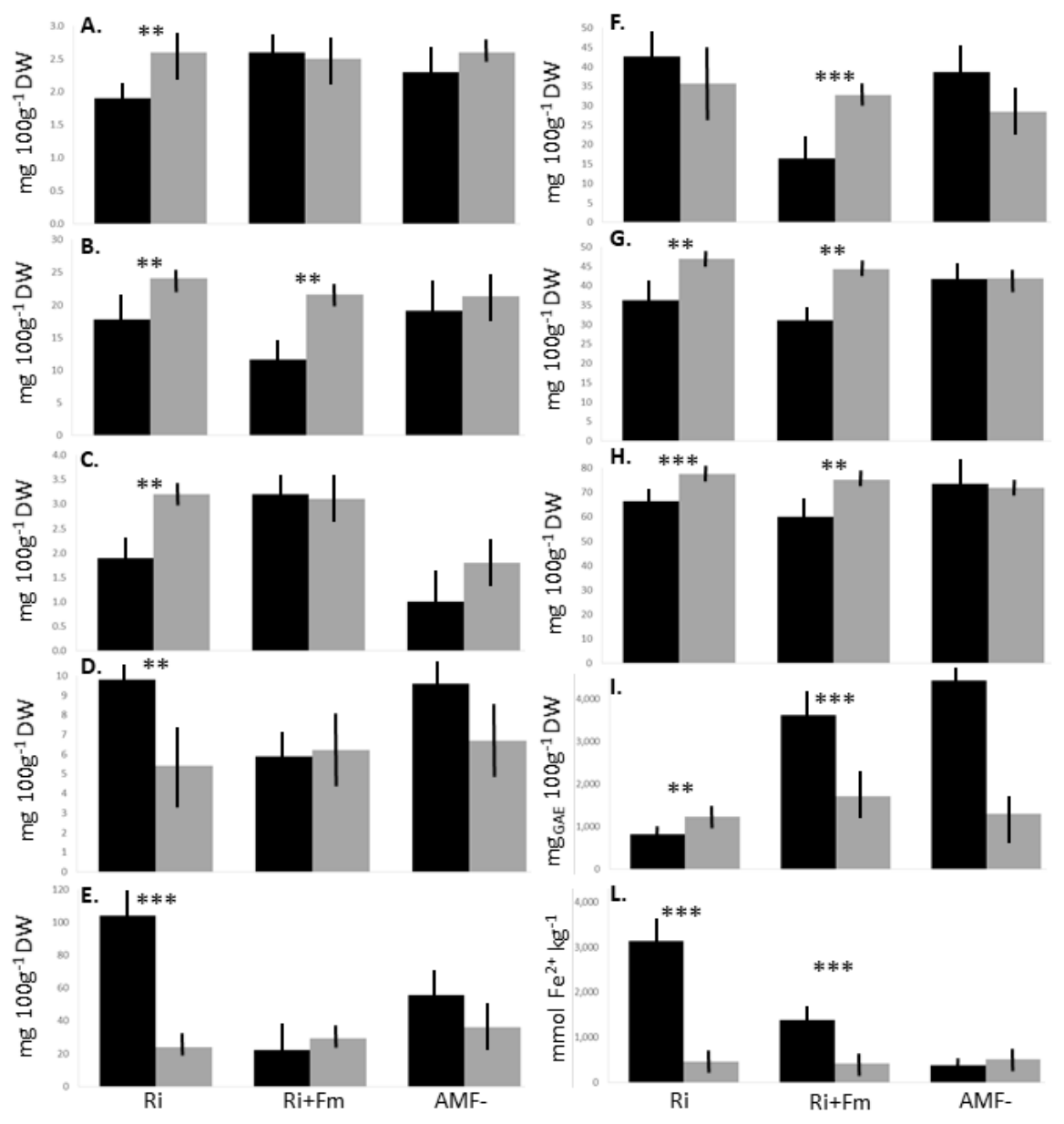

Figure 5. Effects of AMF inoculum consisting of Rhizophagus intraradices alone (Ri), R. intraradices and Funneliformis mosseae ( $\mathrm{Ri}+\mathrm{Fm}$ ) or a control (AMF-) on the content of (A.) isoquercitrin, (B.) quercitrin, (C.) ellagic acid, (D.) epicatechin, (E.) crocin I, (F.) crocin II, (G.) ascorbic acid, (H.) vitamin C, (I.) total polyphenol content (TPC), and (L.) antioxidant activity (FRAP assay) of saffron produced in soilless (black bars) and open field (grey bars, [12]) conditions. Mean comparisons of each treatment in the two cultivation types were performed using an independent samples t-test.

With respect to the nutraceutical compounds, the comparisons are presented in Figure 5. No differences were reported between the untreated corms (AMF-), whereas the application of $\mathrm{Ri}$ in the soilless condition induced an increase in the contents of epicatechin, crocin I, and antioxidant activity $(+80 \%,+435 \%$, and $+675 \%$, respectively), while a decrease in the contents of isoquercitrin, quercitrin, ellagic acid, ascorbic acid, vitamin C, and TPC. Fewer differences were induced by $\mathrm{Ri}+\mathrm{Fm}$, which positively stimulated both the total phenolic content and antioxidant activity $(+210 \%$ and $+325 \%$, respectively), but caused a decrease in quercitrin, crocin II, ascorbic acid, and vitamin C.

\section{Conclusions}

Soilless cultivation in a glasshouse appeared as an effective strategy for the cultivation of saffron with a first-year cultivation spice yield that is comparable with open field production sites. Moreover, the high quality saffron produced via soilless cultivation presented an elevated content of several health-promoting compounds with highly advantageous nutritive properties, such as polyphenols and elevated antioxidant activity. Further studies are needed to define better the methodologies to modulate time and duration of flowering, to improve yield, and to efficiently schedule harvest practices.

Arbuscular mycorrhizal-based products have received great interest in agriculture for their potential to improve crop productivity, nutritional quality, as well as resistance to plant pathogens and 
numerous environmental stresses. The literature highlights that AMF must be chosen by evaluating different aspects, such as the inoculum type, host plants, and the environmental and growing conditions.

Here, AMF successfully colonised C. sativus roots; their effects varied on the basis of inoculum type and cultivation conditions. Among the studied AMF inocula, $R$. intraradices appeared to give more benefits to $C$. sativus than the mix of $R$. intraradices and $F$. mosseae. Specifically, the $R$. intraradices inoculation appeared successful in open field to increase spice yields while in soilless systems to increase the spice quality.

Thus, soilless systems appeared as an effective alternative cultivation strategy for the production of high quality saffron. Further benefits can be obtained by the application of targeted AMF-based biostimulants. A cost-benefit analysis should be performed to assess the economic sustainability.

Author Contributions: M.C., E.L., V.B. and V.S. contributed to the experimental design. M.C., S.D., Í.M.M.V., D.D., A.F. and V.S. acquired and interpreted the data. M.C. drafted the manuscript. V.B. and V.S. conceived the study, coordinated the work and critically revised the manuscript.

Funding: This research was funded by the project titled 'SaffronALP — Lo zafferano di montagna: tecniche sostenibili per una produzione di qualità' - Fondazione Cassa di Risparmio di Torino ( $R F=2017.1966)$ and by the program Interreg V-A Francia Italia Alcotra "Attività innovative per lo sviluppo della filiera transfrontaliera del fiore edule-Antea' n. 1139.

Acknowledgments: The authors acknowledge Dario Sacco for statistical assistance and Alessandro Putzolu for technical assistance.

Conflicts of Interest: The authors declare no conflict of interest.

\section{References}

1. Gresta, F.; Santonoceto, C.; Avola, G. Crop rotation as an effective strategy for saffron (Crocus sativus L.) cultivation. Sci. Hortic. 2016, 211, 34-39. [CrossRef]

2. Maleki, F.; Kazemi, H.; Siahmarguee, A.; Kamkar, B. Development of a land use suitability model for saffron (Crocus sativus L.) cultivation by multi-criteria evaluation and spatial analysis. Eco Eng. 2017, 106, 140-153. [CrossRef]

3. Giorgi, A.; Scheurer, T. Alpine resources: Assets for a promising future-conclusions from the forum alpinum. Mount. Res. Dev. 2015, 35, 414-415. [CrossRef]

4. Husaini, A.; Shafiq, A.; Parvaze, S.; Rather, G.; Parray, A.; Shikari, A.; Javid, M. Bioinformatics for saffron (Crocus sativus L.) improvement. Comm. Biomet. Crop. Sci. 2009, 4, 3-8.

5. Gresta, F.; Lombardo, G.; Siracusa, L.; Ruberto, G. Saffron an alternative crop for sustainable agricultural systems. A review. Agron. Sustain. Dev. 2008, 28, 95-112. [CrossRef]

6. Gresta, F.; Avola, G. Hypothesis on the relation between meteorological data and flowering peaks in saffron (Crocus sativus L.) crop. Acta Hortic. 2017, 1184, 189-194. [CrossRef]

7. Elgazar, A.; Rezq, A.; Bukhari, H. Anti-Hyperglycemic Effect of Saffron Extract in Alloxan-Induced Diabetic Rats. Europ. J. Biol. Sci. 2013, 5, 14-22.

8. Baba, S.; Mohiudin, T.; Basu, S.; Swarnkar, M.; Malik, A.; Abbas, N.; Singh, A.; Ashraf, N. Comprehensive transcriptome analysis of Crocus sativus for discovery and expression of genes involved in apocarotenoid biosynthesis. BMC Genom. 2015, 16, 698. [CrossRef] [PubMed]

9. Lahmass, I.; Touria, L.; Delporte, C.; Sikdar, S.; Antwerpen, P.; Saalaoui, E.; Mégalizzi, V. The waste of saffron crop, a cheap source of bioactive compounds. J. Funct. Foods 2017, 35, 341-351. [CrossRef]

10. Cusano, E.; Consonni, R.; Petrakis, E.A.; Astraka, K.; Cagliani, L.R.; Polissiou, M.G. Integrated analytical methodology to investigate bioactive compounds in Crocus sativus L. flowers. Phytochem. Anal. Phytochem. Analysis 2018, 29, 1-11. [CrossRef]

11. Menghini, L.; Leporini, L.; Vecchiotti, G.; Locatelli, M.; Carradori, S.; Ferrante, C.; Zengin, G.; Recinella, L.; Chiavaroli, A.; Leone, S.; et al. Crocus sativus L. stigmas and byproducts: Qualitative fingerprint, antioxidant potentials and enzyme inhibitory activities. Food Res. Int. 2018, 109, 91-98. [CrossRef]

12. Caser, M.; Maxaieie Victorino, Í.M.; Demasi, S.; Berruti, A.; Donno, D.; Lumini, E.; Bianciotto, V.; Scariot, V. Saffron cultivation in marginal Alpine environments: How AMF inoculation modulates yield and bioactive compounds. Agronomy 2019, 9, 12. [CrossRef] 
13. Talaei, A.; Moghadam, H.; Tabassi, S.; Mohajeri, S. Crocin, the main active saffron constituent, as an adjunctive treatment in major depressive disorder: A randomized, double-blind, placebo-controlled, pilot clinical trial. J. Affect. Disord. 2015, 174, 51-56. [CrossRef]

14. Landi, R. Lo zafferano: Tradizione e qualità. Camera di commercio: Industria, Artigianato e Agricoltura di Firenze; CCIAA (Camera di Commercio: Industria, Artigianato e Agricoltura): Firenze, Italy, 2007; Volume 4, p. 65.

15. Lachaud, C. La Bible du Safranier. Tout savoir sur le Crocus sativus et sur le Safran, 1st ed.; La Paradisière: Correze, France, 2012; ISBN 978-2-7466-4412-0.

16. De Juan, J.A.; Córcoles, H.L.; Muñoz, R.M.; Picornell, M.R. Yield and yield components of saffron under different cropping systems. Ind. Crops Prod. 2009, 30, 212-219. [CrossRef]

17. Yarami, N.; Kamgar-Haghighi, A.A.; Sepaskhah, A.R.; Zand-Parsa, S. Determination of the potential evapotranspiration and crop coefficient for saffron using a water-balance lysimeter. Arch. Agr. Soil Sci. 2011, 57, 727-740. [CrossRef]

18. Molina, R.; Valero, M.; Navarro, Y.; Guardiola, J.; García-Luis, A. Temperature effects on flower formation in saffron (Crocus sativus L.). Sci. Hortic. 2005, 103, 361-379. [CrossRef]

19. Maggio, A.; Raimondi, G.; Martino, A.; De Pascale, S. Soilless cultivation of saffron in mediterranean environment. Acta Hortic. 2006, 718, 515-522. [CrossRef]

20. Benschop, M. Crocus; De Hertogh, A., Le Nard, M., Eds.; The Physiology of Flower Bulbs, Elsevier Science Publishers: Amsterdam, The Netherlands, 1993; pp. 257-272.

21. De Mastro, G.; Ruta, C. Relation between corm size and saffron (Crocus sativus L.) flowering. Acta Hortic. 1993, 334, 512-517. [CrossRef]

22. Douglas, M.H.; Smallfield, B.M.; Wallace, A.R.; McGimpsey, J.A. Saffron (Crocus sativus L.): The effect of mother corm size on progeny multiplication, flower and stigma production. Sci. Hortic. 2014, 166, 50-58. [CrossRef]

23. Kumar, R. Calibration and validation of regression model for non-destructive leaf area estimation of saffron (Crocus sativus L.). Sci. Hortic. 2009, 122, 142-145. [CrossRef]

24. Mollafilabi, A.; Koocheki, A.; Moeinerad, H.; Kooshki, L. Effect of plant density and weight of corm on yield and yield components of saffron (Crocus sativus L.) under soil, hydroponic and plastic tunnel cultivation. Acta Hortic. 2013, 997, 51-58. [CrossRef]

25. Putra, P.A.; Yuliando, H. Soilless culture system to support water use efficiency and product quality: A review. Agric. Agricult. Sci. Proc. 2015, 3, 283-288. [CrossRef]

26. Augé, R.M.; Toler, H.D.; Saxton, A.M. Arbuscular mycorrhizal symbiosis alters stomatal conductance of host plants more under drought than under amply watered conditions: A meta-analysis. Mycorrhiza 2015, 25, 13-24. [CrossRef] [PubMed]

27. Helal Beigi, Y.; Khoshgoftar, M.; Shamsi, A.; Zamani, N. Possibility of saffron corm growth in different bed of cultivation in soilless system. In Proceedings of 1st Congress of Hydroponic in Greenhouse Production; Isfahan University of Technology: Isfahan, Iran, 2009.

28. Sourell, F.; Weathers, P. The growth of saffron (Crocus sativus L.) in aeroponics and hydroponics. J. Herb. Spices Med. Plants 2000, 7, 113-127.

29. Du Jardin, P. Plant biostimulants: Definition, concept, main categories and regulation. Sci. Hortic. 2015, 196, 3-14. [CrossRef]

30. Rouphael, Y.; Franken, P.; Schneider, C.; Schwarz, D.; Giovannetti, M.; Agnolucci, M.; De Pascale, S.; Bonini, P.; Colla, G. Arbuscular mycorrhizal fungi acta s biostimulants in horticultural crops. Sci. Hortic. 2015, 196, 91-108. [CrossRef]

31. Berruti, A.; Lumini, E.; Balestrini, R.; Bianciotto, V. Arbuscular mycorrhizal fungi as natural biofertilizers: Let's benefit from past successes. Front. Microbiol. 2016, 6, 1559. [CrossRef]

32. Smith, S.E.; Read, D.J. Mycorrhizal Symbiosis; Academic Press: London, UK, 1997; Volume 40, p. 154.

33. Todeschini, V.; Lahmidi, N.A.; Mazzucco, E.; Marsano, F.; Gosetti, F.; Robotti, E.; Bona, E.; Massa, N.; Bonneau, L.; Marengo, E.; et al. Impact of beneficial microorganisms on strawberry growth, fruit production, nutritional quality, and volatilome. Front. Plant. Plant Sci. 2018, 9, 1611. [CrossRef] [PubMed]

34. Pellegrino, E.; Bedini, S. Enhancing ecosystem services in sustainable agriculture: Biofertilization and biofortification of chickpea (Cicer arietinum L.) by arbuscular mycorrhizal fungi. Soil Biol. Biochem. 2014, 68, 429-439. [CrossRef] 
35. Zeng, Y.; Guo, L.; Chen, B.; Hao, Z.; Wang, J.; Huang, L.; Yang, G.; Cui, X.; Yang, L.; Wu, Z.; et al. Arbuscular mycorrhizal symbiosis and active ingredients of medicinal plants: Current research status and prospectives. Mycorrhiza 2013, 23, 253-265. [CrossRef] [PubMed]

36. Giovannetti, M.; Avio, L.; Sbrana, C. Improvement of nutraceutical value of food by plant symbionts; Ramawat, K.G., Merillon, J.M., Eds.; Natural Products, Phytochemistry, Botany and Metabolism of Alkaloids, Phenolics and Terpenes; Springer: Berlin/Heidelberg, Germany, 2013; pp. 2641-2662.

37. Swamy, M.K.; Akhtar, M.S.; Sinniah, U.R. Response of PGPR and AM fungi toward growth and secondary metabolite production in medicinal and aromatic plants; Hakeem, K., Akhtar, M., Eds.; Plant, Soil and Microbes; Springer: Heidelberg, Germany, 2016.

38. Avio, L.; Turrini, A.; Giovannetti, M.; Sbrana, C. Designing the ideotype mycorrhizal symbionts for the production of healthy food. Front. Plant Sci. 2018, 9, 1089. [CrossRef] [PubMed]

39. De Sousa Oliveira, M.; da Silva Campos, M.; de Albuquerque, U.P.; da Silva, F.S.B. Arbuscular mycorrhizal fungi (AMF) affects biomolecules content in Myracrodruon urundeuva seedlings. Ind. Crops Prod. 2013, 50, 244-247. [CrossRef]

40. Aimo, S.; Gosetti, F.; D’Agostino, G.; Gamalero, E.; Gianotti, V.; Bottaro, M.; Gennaro, M.; Berta, G. Use of arbuscular mycorrhizal fungi and beneficial soil bacteria to improve yield and quality of saffron (Crocus sativus L.). Acta Hortic. 2010, 850, 159-162. [CrossRef]

41. Lone, R.; Shuab, R.; Koul, K. AMF association and their effect on metabolite mobilization, mineral nutrition and nitrogen assimilating enzymes in saffron (Crocus sativus) plant. J. Plant Nutr. 2016, 39, 1852-1862. [CrossRef]

42. Shajari, M.A.; Moghaddam, P.R.; Ghorbani, R.; Koocheki, A. Increasing saffron (Crocus sativus L.) corm size through the mycorrhizal inoculation, humic acid application and irrigation managements. J. Plant Nutr. 2018, 41, 1047-1064. [CrossRef]

43. Mohebi-Anabat, M.; Riahi, H.; Zanganeh, S.; Sadeghnezhad, E. Effects of arbuscular mycorrhizal inoculation on the growth, photosynthetic pigments and soluble sugar of Crocus sativus L. (saffron) in autoclaved soil. Int. J. Agron. Agric. Res. 2015, 6, 296-304.

44. ISO 3632-1:2011. Spices-Saffron (Crocus sativus L.); Food products SC 7, Spices, culinary herbs and condiments; International Organization for Standardization: Geneva, Switzerland, September 2011.

45. Giorgi, A.; Pentimalli, D.; Giupponi, L.; Panseri, S. Quality traits of saffron (Crocus sativus L.) produced in the Italian Alps. Open Agriculture 2017, 2, 52-57. [CrossRef]

46. Donno, D.; Mellano, M.G.; Prgomet, Z.; Beccaro, G.L. Advances in Ribes x nidigrolaria Rud. Bauer \& A. Bauer fruits as potential source of natural molecules: A preliminary study on physico-chemical traits of an underutilized berry. Sci. Hortic. 2018, 237, 20-27.

47. Donno, D.; Mellano, M.G.; Prgomet, Z.; Cerutti, A.K.; Beccaro, G.L. Phytochemical characterization and antioxidant activity evaluation of Mediterranean medlar fruit (Crataegus azarolus L.): Preliminary study of underutilized genetic resources as a potential source of health-promoting compound for food supplements. J. Food Nutrit. Res. 2017, 56, 18-31.

48. Caser, M.; D’Angiolillo, F.; Chitarra, W.; Lovisolo, C.; Ruffoni, B.; Pistelli, L.; Pistelli, L.; Scariot, V. Ecophysiological and phytochemical responses of Salvia sinaloensis Fern. to drought stress. Plant Growth Regul. 2018, 84, 383-394. [CrossRef]

49. Caser, M.; Chitarra, W.; D'Angiolillo, F.; Perrone, I.; Demasi, S.; Lovisolo, C.; Pistelli, L.; Pistelli, L.; Scariot, V. Drought stress adaptation modulates plant secondary metabolite production in Salvia dolomitica Codd. Ind. Crop Prod. 2019, 129, 85-96. [CrossRef]

50. Hoch, H.C. Freeze-substitution of fungi; Aldrich, H.C., Todd, W.J., Eds.; Ultrastructure techniques of microorganisms; Plenum Press: New York, NY, USA, 1986; pp. 183-211.

51. Reynolds, E.S. The use of lead citrate at high $\mathrm{pH}$ as an electron-opaque stain in electron microscopy. J. Cell. Biol. 1963, 17, 208-212. [CrossRef]

52. Gresta, F.; Avola, G.; Lombardo, G.M.; Siracusa, L.; Ruberto, G. Analysis of flowering, stigmas yield and qualitative traits of saffron (Crocus sativus L.) as affected by environmental conditions. Sci. Hortic. 2009, 119, 320-324.

53. Cavusoglu, A.; Erkel, E. The effect of different planting areas and corm size on yield and harvest period of saffron (Crocus sativus L.) in Kocaeli province. J. Akdeniz Univ. Faculty Agric. 2005, 18, 179-184. 
54. Koocheki, A.; Seyyedi, S. How irrigation rounds and mother corm size control saffron yield, quality, daughter corms behavior and phosphorus uptake. Sci. Hortic. 2016, 213, 132-143. [CrossRef]

55. Turhan, H.; Kahriman, F.; Egesel, C.; Kemal Gul, M. The effects of different growing media on flowering and corm formation of saffron (Crocus sativus L.). Afr. J. Biotech. 2007, 6, 2328-2332.

56. Karimi, E.; Oskoueian, E.; Hendra, R.; Jaafar, H. Evaluation of Crocus sativus L. stigma phenolic and flavonoid compounds and its antioxidant activity. Molecules 2010, 15, 6244-6256. [CrossRef]

57. Asdaq, S.; Inamdar, M. Potential of garlic and its active constituent, S-allyl cysteine, as antihypertensive and cardioprotective in presence of captopril. Phytomedicine 2010, 17, 1016-1026. [CrossRef] [PubMed]

58. Makhlouf, H.; Saksouk, M.; Habib, J.; Chahine, R. Determination of antioxidant activity of saffron taken from the flower of Crocus sativus grown in Lebanon. Afr. J. Biotech. 2011, 10, 8093-8100.

59. Ordoudi, S.; Befani, C.; Nenadis, N.; Koliakos, G.; Tsimidou, M. Further Examination of Antiradical Properties of Crocus sativus Stigmas Extract Rich in Crocins. J. Agric. Food Chem. 2009, 57, 3080-3086. [CrossRef]

60. Siracusa, L.; Gresta, F.; Avola, G.; Lombardo, G.M.; Ruberto, G. Influence of corm provenance and environmental condition on yield and apocarotenoid profiles in saffron (Crocus sativus L.). J. Food Comp. Anal. 2010, 23, 394-400. [CrossRef]

61. Manzo, A.; Panseri, S.; Bertoni, D.; Giorgi, A. Economic and qualitative traits of Italian Alps saffron. J. Mt. Sci. 2015, 12, 1542-1550. [CrossRef]

62. Sánchez-Vioque, R.; Rodríguez-Conde, M.F.; Reina-Ureña, J.V.; Escolano-Tercero, M.A.; Herraiz-Peñalver, D.; Santana-Méridas, O. In vitro antioxidant and metal chelating properties of corm, tepal and leaf from saffron (Crocus sativus L.). Ind. Crop Prod. 2012, 39, 149-153. [CrossRef]

63. Rahaiee, S.; Moini, S.; Hashemi, M.; Shojaosadati, S. Evaluation of antioxidant activities of bioactive compounds and various extracts obtained from saffron (Crocus sativus L.): A review. J. Food Sci. Tech. 2015, 52, 1881-1888. [CrossRef] [PubMed]

64. Shahi, T.; Assadpour, E.; Jafari, S. Main chemical compounds and pharmacological activities of stigmas and tepals of 'red gold'; saffron. Trends Food Sci. Technol. 2016, 58, 69-78. [CrossRef]

65. Donno, D.; Mellano, M.G.; Raimondo, E.; Cerutti, A.K.; Prgomet, Z.; Beccaro, G.L. Influence of applied drying methods on phytochemical composition in fresh and fried goji fruits by HPLC fingerprint. Eur. Food Res. Technol. 2016, 242, 1961-1974. [CrossRef]

66. Heidari, M.; Karami, V. Effects of different mycorrhiza species on grain yield, nutrient uptake and oil content of sunflower under water stress. J. Saudi Soc. Agric. Sci. 2014, 13, 9-13. [CrossRef]

67. Araim, G.; Saleem, A.; Arnason, J.T.; Charest, C. Root colonization by arbuscular mycorrhizal (AM) fungus increases growth and secondary metabolism of purple coneflower, Echinacea purpurea (L.) Moench. J. Agric. Food Chem. 2009, 57, 2255-2258. [CrossRef]

68. Ceccarelli, N.; Curadi, M.; Martelloni, L.; Sbrana, C.; Picciarelli, P.; Giovannetti, M. Mycorrhizal colonization impacts on phenolic content and antioxidant properties of artichoke leaves and flower heads two years after field transplant. Plant Soil 2010, 335, 311-323. [CrossRef]

69. Avio, L.; Sbrana, C.; Giovannetti, M.; Frassinetti, S. Arbuscular mycorrhizal fungi affect total phenolics content and antioxidant activity in leaves of oak leaf lettuce varieties. Sci. Hortic. 2017, 224, 265-271. [CrossRef]

70. Toussaint, J.P.; Smith, F.A.; Smith, S.E. Arbuscular mycorrhizal fungi can induce the production of phytochemicals in sweet basil irrespective of phosphorus nutrition. Mycorrhiza 2007, 17, 291-297. [CrossRef]

71. Nell, M.; Vötsch, M.; Vierheilig, H.; Steinkellner, S.; Zitterl-Eglseer, K.; Franz, C.; Novak, J. Effect of phosphorus uptake on growth and secondary metabolites of garden (Salvia officinalis L.). J. Sci. Food Agric. 2009, 89, 1090-1096. [CrossRef]

72. Geneva, M.P.; Stancheva, I.V.; Boychinova, M.M.; Mincheva, N.H.; Yonova, P.A. Effects of foliar fertilization and arbuscular mycorrhizal colonization on Salvia officinalis L. growth, antioxidant capacity, and essential oil composition. J. Sci. Food Agric. 2010, 90, 696-702.

73. Donno, D.; Beccaro, G.; Mellano, M.; Cerutti, A.; Bounous, G. Goji berry fruit (Lycium spp.): Antioxidant compound fingerprint and bioactivity evaluation. J. Funct. Foods 2015, 18, 1070-1085. [CrossRef]

74. Vasco, C.; Ruales, J.; Kamal-Eldin, A. Total phenolic compounds and antioxidant capacities of majpr fruits from Ecuador. Food Chem. 2008, 111, 816-823. [CrossRef] 
75. Donno, D.; Cerutti, A.K.; Prgomet, I.; Mellano, M.G.; Beccaro, G.L. Foodomics for mulberry fruit (Morus spp.): Analytical fingerprint as antioxidants' and health properties' determination tool. Food Res. Int. 2015, 69, 179-188. [CrossRef]

76. Ma, H.; Johnson, S.L.; Liu, W.; DaSilva, N.A.; Meschwitz, S.; Dain, J.A.; Seeram, N.P. Evaluation of polyphenol anthocyanin-enriched extracts of blackberry, black raspberry, blueberry, cranberry, res raspberry, and strawberry for free radical scavenging, reactive carbonyl species trapping, anti-glycation, anti- $\beta$-amyloid aggregation, and microglial neuroprotective effects. Int. J. Mol. Sci. 2018, 19, 461.

(C) 2019 by the authors. Licensee MDPI, Basel, Switzerland. This article is an open access article distributed under the terms and conditions of the Creative Commons Attribution (CC BY) license (http://creativecommons.org/licenses/by/4.0/). 